\title{
Apoptosis Induction by Polygonum minus Is Related to Antioxidant Capacity, Alterations in Expression of Apoptotic-Related Genes, and S-Phase Cell Cycle Arrest in HepG2 Cell Line
}

\author{
Mohd Alfazari Mohd Ghazali, ${ }^{1,2,3}$ Ghanya Al-Naqeb, ${ }^{4}$ \\ Kesavanarayanan Krishnan Selvarajan, ${ }^{1,2}$ Mizaton Hazizul Hasan, ${ }^{1,2}$ and Aishah Adam ${ }^{1,2}$ \\ ${ }^{1}$ Pharmacology and Toxicology Research Laboratory, Faculty of Pharmacy, University Technology MARA (UiTM), \\ 42300 Bandar Puncak Alam, Selangor Darul Ehsan, Malaysia \\ ${ }^{2}$ Group on Affinity, Efficacy and Safety Studies (OASES), Brain and Neuroscience Communities of Research, \\ University Technology MARA (UiTM), 40450 Shah Alam, Selangor Darul Ehsan, Malaysia \\ ${ }^{3}$ School of Pharmaceutical Sciences, University Science of Malaysia (USM), 11800 Minden, Penang, Malaysia \\ ${ }^{4}$ Department of Food Sciences and Technology, Faculty of Agriculture, University of Sana'a, Sana'a, Yemen
}

Correspondence should be addressed to Aishah Adam; aishah_adam@puncakalam.uitm.edu.my

Received 27 February 2014; Accepted 10 April 2014; Published 13 May 2014

Academic Editor: Joohun Ha

Copyright (C) 2014 Mohd Alfazari Mohd Ghazali et al. This is an open access article distributed under the Creative Commons Attribution License, which permits unrestricted use, distribution, and reproduction in any medium, provided the original work is properly cited.

\begin{abstract}
Polygonum minus (Polygonaceae) is a medicinal herb distributed throughout eastern Asia. The present study investigated antiproliferative effect of $P$. minus and its possible mechanisms. Four extracts (petroleum ether, methanol, ethyl acetate, and water) were prepared by cold maceration. Extracts were subjected to phytochemical screening, antioxidant, and antiproliferative assays; the most bioactive was fractionated using vacuum liquid chromatography into seven fractions (F1-F7). Antioxidant activity was measured via total phenolic content (TPC), 2,2-diphenyl-1-picrylhydrazyl (DPPH), and ferric reducing antioxidant power (FRAP) assays. Antiproliferative activity was evaluated using 3-(4,5-dimethylthiazol-2-yl)-2,5-diphenyltetrazolium bromide (MTT) assay. Most active fraction was tested for apoptosis induction and cell cycle arrest in HepG2 cells using flow cytometry and confocal microscopy. Apoptotic-related gene expression was studied by RT-PCR. Ethyl acetate extract was bioactive in initial assays. Its fraction, F7, exhibited highest antioxidant capacity (TPC; $113.16 \pm 6.2 \mathrm{mg}$ GAE/g extract, DPPH; EC 50 : $30.5 \pm 3.2 \mu \mathrm{g} / \mathrm{mL}, \mathrm{FRAP}$; $1169 \pm 20.3 \mu \mathrm{mol} \mathrm{Fe}(\mathrm{II}) / \mathrm{mg}$ extract) and selective antiproliferative effect $\left(\mathrm{IC}_{50}: 25.75 \pm 1.5 \mu \mathrm{g} / \mathrm{mL}\right)$. F7 induced apoptosis in concentration- and time-dependent manner and caused cell cycle arrest at S-phase. Upregulation of proapoptotic genes (Bax, $p 53$, and caspase-3) and downregulation of antiapoptotic gene, $\mathrm{Bcl}$-2, were observed. In conclusion, F7 was antiproliferative to HepG2 cells by inducing apoptosis, cell cycle arrest, and via antioxidative effects.
\end{abstract}

\section{Introduction}

Apoptosis plays an important role in cancer development and is a target for enhancing understanding of cancer and in development of anticancer treatment. Apoptosis is a highly regulated process characterized by cleavage of proteins and activation of caspases in viable cells resulting in
DNA fragmentation, chromatin condensation, membrane blebbing, and cell shrinkage [1]. This process is essential for homeostatic mechanism to maintain cellular integrity by removing unwanted, redundant, and damaged cells by noninflammatory ways. However, in many cancer cells, apoptosis is dysregulated due to multiple genetic aberrations and cellular stress, conferring resistance to death in these 
cells which then stay longer in circulation. In the last two decades, extensive studies aimed at improving understanding of intrinsic signaling pathways that control execution of apoptosis in cancer cells were undertaken. These include the use of antiapoptotic proteins and stimulation of proapoptotic proteins as part of treatment strategy for cancer [2]. Carcinogenesis is also related to excessive free radical formation. Many studies have shown that reactive oxygen species (ROS), reactive nitrogen species (RNS), and other metabolism byproducts can cause DNA mutation leading to initiation and progression of cancer. Endogenous and exogenous antioxidants can antagonize the promotion phase of carcinogenesis in many types of malignancies through detoxication of these free radicals [3]. Antioxidants from plants with apoptosisinducing capabilities have drawn a lot of interest in cancer research due to cost effectiveness as they are abundant in nature and supposedly have fewer side effects than synthetic antioxidants. Much work has been conducted on herbs with antioxidant and anticancer effects [4].

Polygonum minus, family Polygonaceae, is locally known as "kesum" in Malaysia. It is extensively used in certain types of Malay dishes such as "laksa" or "asam pedas." It is used traditionally to treat rheumatism, indigestion, and kidney stones and to control hair dandruff. Researchers have linked the pharmacological effects of this plant to its high antioxidant capacity. Aqueous, methanolic, and ethanolic extracts of this plant showed high antioxidant activity which was contributed mostly by its phenolic compounds [5-9]. Fractions from ethanolic and aqueous extract demonstrated gastroprotective effect by inhibiting ulcer lesions in stomach wall of ethanol-induced gastric ulcer in rats $[10,11]$. Antimicrobial activities against several strains of bacteria were shown and moderate antiproliferative effect was observed in human cervical carcinoma $(\mathrm{HeLa})$ cell line with $\mathrm{IC}_{50}$ of approximately $30 \mu \mathrm{g} / \mathrm{mL}$ with ethanolic extract [12]. No cytotoxicity was seen in normal human lung fibroblast cell line $(\mathrm{Hs} 888 \mathrm{Lu})$ that was exposed to aqueous and ethanolic extracts [13]. Determination of acute and subacute oral toxicities of aqueous extract in Wistar rats at the highest dose gave no significant changes in food and water intake, behavior, blood chemistry, hematology parameters, and neurological assessment [14].

The present study was undertaken to assess the antiproliferative activity and antioxidant capacity of $P$. minus and to examine mechanism(s) of action of the most active fraction. This involved identification of the most bioactive crude extract in terms of high antioxidant activity and potent antiproliferative activity. This crude extract was further subjected to chromatographic fractionation and retested. The fraction with smallest $\mathrm{IC}_{50}$ in antiproliferative assay using HepG2 cells was assessed for apoptosis induction by looking at cell cycle arrest and expression of several apoptotic-related genes.

\section{Materials}

2.1. Chemicals. Petroleum ether, methanol, hexane, and ethyl acetate were purchased from Fisher Scientific, USA. Silica gel $60 \mathrm{PF}_{254}$ was procured from Merck, Germany.
Folin-Ciocalteu reagent, 2,2-diphenyl-1-picrylhydrazyl, MTT powder, 2,4,6-tris(2-pyridyl)-s-triazine, sodium carbonate, copper sulfate, sodium chloride, sodium potassium tartrate, phosphate buffered saline $\mathrm{pH} 7.4$ (PBS), and gallic acid were acquired from Sigma, USA. Annexin-V and propidium iodide (PI) were obtained from Becton Dickinson, USA. Total RNA Isolation kit and TUNEL assay kit were bought from Promega, USA. All primers were synthesized by Beacon designer, Premier Biosoft International.

2.2. Plant Material. Plant material was procured in Seri Kembangan, Selangor, Malaysia. Plant was identified by $\mathrm{Dr}$ Shamsul Khamis, Institute of Bioscience, University Putra Malaysia, and a voucher specimen SK 2105/12 was deposited at the herbarium of Atta-ur-Rahman Research Institute of Natural Products (AURiND UiTM).

\section{Methods}

3.1. Study Design. The flow chart of the study is shown in Figure 1.

3.2. Extraction and Fractionation. Leaves were manually picked from stems. Fresh leaves of $P$. minus were dried at room temperature for $24 \mathrm{~h}$ and subjected to $40^{\circ} \mathrm{C}$ oven for a week to dry completely. Dried leaves were chopped finely into powder form using a commercial grinder for $15 \mathrm{~min}$. Plant powder was soaked in several organic solvents petroleum ether, methanol $(\mathrm{MeOH})$, ethyl acetate (EtOAc), and water for 24 up to $72 \mathrm{~h}$ in a ratio of $1: 20 \mathrm{w} / \mathrm{v}$ as per methods described earlier [15]. The extract was filtered using filter paper Whatman number 1 before being dried at reduced pressure in rotary evaporator (Büchi, Switzerland) to give a green colored extract. Vacuum liquid chromatography (VLC) method was employed to separate the most bioactive crude extract. Silica gel $60 \mathrm{PF}_{254}$ was packed into the VLC column $(10 \mathrm{~cm} \times 10 \mathrm{~cm})$ and washed with hexane until fully packed. The crude extract $(10 \mathrm{~g})$ was dissolved in ethyl acetate and preabsorbed onto silica gel 60 . The column was then eluted via gradient elution with a combination of hexane and ethyl acetate in a ratio $9.5: 0.5$. The yield was collected into small bottles and pooled based on thin layer chromatography (TLC) pattern.

3.3. Phytochemical Screening. Extract $(20 \mathrm{mg})$ was dissolved in $10 \mathrm{~mL}$ of $\mathrm{MeOH}$ and filtered. Filtrate $(1 \mathrm{~mL})$ was transferred into two test tubes and a few drops of concentrated $\mathrm{HCl}$ were added. To test for flavonoids, the first tube was shaken for $2 \mathrm{~min}$, and a piece of magnesium powder was then added. A positive result was indicated by a change in color of the sample to red. The second tube was shaken for $2 \mathrm{~min}$ and a few drops of Mayer's reagent were added. Formation of a yellow-cream precipitate showed presence of alkaloids. To detect presence of saponins in extract, $500 \mathrm{mg}$ of extract was mixed with $5 \mathrm{~mL}$ distilled water $\left(\mathrm{dH}_{2} \mathrm{O}\right)$ in a test tube which was then shaken vigorously. Formation of a stable froth for at least $15 \mathrm{~min}$ indicated presence of saponins. 


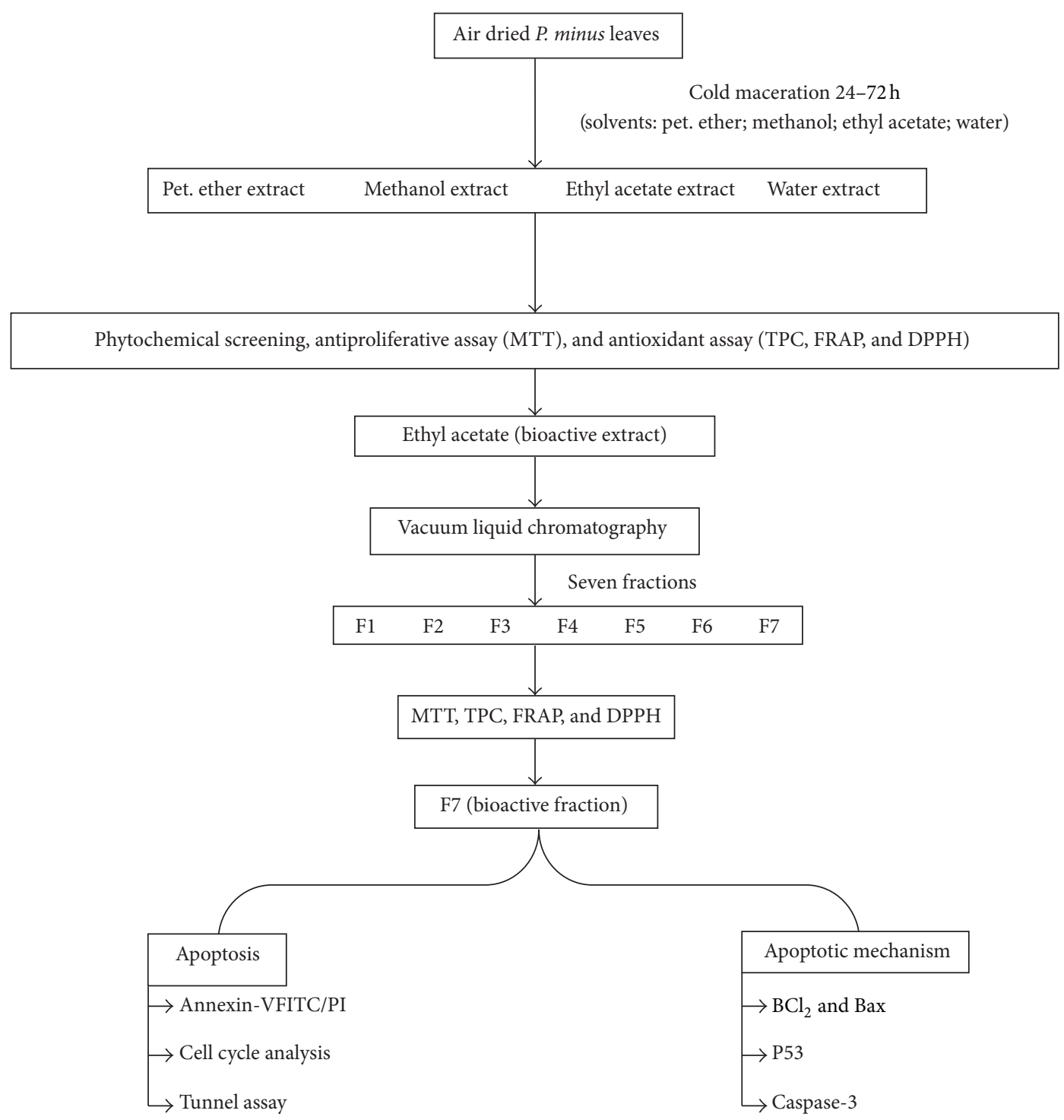

FIgURE 1: Flowchart of study.

\subsection{Determination of Antioxidant Capacity}

3.4.1. Total Phenolic Content Assay. Total phenolic content (TPC) was measured using procedures described earlier [16]. Gallic acid was used as standard against which TPC of every fraction was compared. Sodium carbonate, copper sulfate, and sodium potassium tartrate in the ratio of $100: 1: 1$ was mixed well and prepared fresh before experiment. The mixture was pipetted into tubes containing test sample or standard and left for $15 \mathrm{~min}$. After this time, a mixture of Folin-Ciocalteu reagent and water $(1: 3)$ was added whilst vortexing. The mixture was allowed to stand at room temperature for $35 \mathrm{~min}$ in the dark. Absorbance was read spectrophotometrically at $750 \mathrm{~nm}$.

3.4.2. DPPH Scavenging Assay. Principle of this assay is to detect ability of test sample to reduce DPPH free radicals. Method of [17] was used. DPPH was dissolved in ethanol 50\%

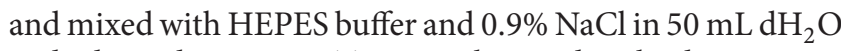
and adjusted to $\mathrm{pH}$ 7.4. Test sample was dissolved in $\mathrm{MeOH}$. Sample $(5 \mu \mathrm{L})$ was added to $195 \mu \mathrm{L}$ of ice cold DPPH solution and allowed to stand at room temperature for $30 \mathrm{~min}$. Test sample was then transferred to clear and transparent 96well plates and was read using a microplate reader (Sunrise, Tecan, Switzerland) at $517 \mathrm{~nm}$. Percent scavenging effect was calculated using the formula:

$$
\% \text { scavenging effect }=(\mathrm{Ac}-\mathrm{As} / \mathrm{Ac}) \times 100,
$$

where Ac is absorbance of control and As is absorbance of sample.

3.4.3. Ferric Reducing Antioxidant Power (FRAP) Assay. Antioxidant activity was measured using a modified FRAP assay method [18]. FRAP values were obtained by comparing the absorbance change at $593 \mathrm{~nm}$ in test reaction mixtures with those containing ferrous ions in known concentration. 


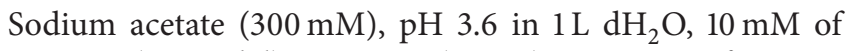
2,4,6-tris(2-pyridyl)-s-triazine (TPTZ) in $100 \mathrm{~mL}$ of $40 \mathrm{mM}$ $\mathrm{HCL}$, and $20 \mathrm{mM}$ ferric chloride were combined in a ratio of $10: 1: 1(\mathrm{v} / \mathrm{v} / \mathrm{v})$ fresh prior to experiment. Test samples $(100 \mu \mathrm{L})$ were mixed with $3 \mathrm{~mL}$ of FRAP reagent and allowed to stand at room temperature for $4 \mathrm{~min}$ before reading the absorbance spectrophotometrically at $593 \mathrm{~nm}$. The FRAP value was expressed as $\mu \mathrm{mol} \mathrm{Fe}$ (II)/mg dry weight of extract. $\mathrm{FeSO}_{4}(2 \mathrm{mM})$ was used to construct a standard curve.

\subsection{Antiproliferative Activity}

3.5.1. MTT Assay. MTT assay was performed as previously described [19]. Crude extract was dissolved in 100\% dimethyl sulfoxide (DMSO) and prepared fresh prior to assay. Cells $(2 \times$ $10^{4}$ /well) were plated in 96-well plate and incubated at $37^{\circ} \mathrm{C}$ for $24 \mathrm{~h}$. Next day, cells were treated with the crude extract in DMSO $(<0.5 \%)$ and the plate was incubated for $72 \mathrm{~h}$. Then, MTT solution $(50 \mu \mathrm{L})$ was added into each well and incubated for $4 \mathrm{~h}$. Supernatant in each well was then collected and DMSO $(100 \mu \mathrm{L})$ was used to dissolve the formazan crystal in the well. The plate was read with a microplate reader at $570 \mathrm{~nm}$.

3.6. Flow Cytometry Analysis. Flow cytometry analysis was carried out to investigate proportion of cancer cells undergoing apoptosis using annexin-V conjugated with fluorescein isothiocyanate (FITC) detection kit according to manufacturer's instructions. Cells $\left(1 \times 10^{6} /\right.$ well $)$ were seeded onto 24 well plates and incubated at $37^{\circ} \mathrm{C}$ overnight. Next day, cells were treated with various concentrations of the extract and incubated for 24,48 , and $72 \mathrm{~h}$, respectively. After this, cells were detached using trypsin for $5 \mathrm{~min}$. Cells were collected and centrifuged at $1000 \mathrm{rpm}$ for $5 \mathrm{~min}$. Cell pellet was washed with PBS and resuspended in $100 \mu \mathrm{L}$ binding buffer. Subsequently, $2.5 \mu \mathrm{L}$ annexin V-FITC and $3 \mu \mathrm{L}$ propidium iodide (PI) were added and kept in the dark at room temperature for 15 min. Annexin V-FITC/PI stained cells were analyzed using flow cytometry (FACSCalibur, Becton Dickinson, USA).

3.7. Cell Cycle Analysis. Cells were treated as described in flow cytometry analysis. After treatment and incubation for 24 and $48 \mathrm{~h}$, cells were harvested and fixed with ice-cold $70 \%$ ethanol $(1 \mathrm{~mL})$ at $-20^{\circ} \mathrm{C}$ for $2 \mathrm{~h}$. Ethanol was then removed $(1000 \mathrm{rpm}, 5 \mathrm{~min})$ and the cells were washed twice with cold PBS. Subsequently, cells were resuspended in $425 \mu \mathrm{L}$ of PBS, $25 \mu \mathrm{L}$ PI $(1 \mathrm{mg} / \mathrm{mL})$, and $50 \mu \mathrm{L}$ RNaseA $(1 \mathrm{mg} / \mathrm{mL})$ and incubated for $30 \mathrm{~min}$ at room temperature. Distribution of the cell cycle was measured by flow cytometer and data analysis was carried out with ModFitLT software (version 4) [20].

3.8. TUNEL Assay. TUNEL assay was performed as per procedures described in the kit (DeadEnd Fluorometric TUNEL System kit, Promega, USA). HepG2 cells $\left(0.5 \times 10^{6} /\right.$ well $)$ were plated in fluorometric dish overnight. The next day, cells were treated with F7 and incubated for $48 \mathrm{~h}$. Staining protocol was carried out according to manufacturer's instructions of the kit. Specimens were viewed under fluorescence confocal microscope (Leica TCS SPE, Germany) to identify apoptotic cells.

3.9. Gene Expression Studies. HepG 2 cells were seeded in T25 flasks and allowed to attain $70-80 \%$ confluency. The next day, cells were treated with F7 for $48 \mathrm{~h}$ using three concentrations $(12.5,25$, and $37.5 \mu \mathrm{g} / \mathrm{mL})$. These concentrations were determined from preliminary experiments to determine growth-response curves by MTT assay and verified by flow cytometry. They correspond to $\mathrm{IC}_{25}, \mathrm{IC}_{50}$, and $\mathrm{IC}_{75}$, respectively. Total RNA extraction was carried out using the procedures described in Total RNA Isolation kit (Promega, USA). Concentration of RNA was calculated using biophotometer (BioRad, USA) and purity of RNA was determined. Mastermix $(12.5 \mu \mathrm{L})$ containing SYBR green dye as detector was added with $1.5 \mu \mathrm{L}$ of pure RNA, $0.5 \mu \mathrm{L}$ RNase, $1 \mu \mathrm{L}$ of each forward and reverse primers, and $8.5 \mu \mathrm{L}$ of $\mathrm{dH}_{2} \mathrm{O}$ to give a final reaction mixture of approximately $25 \mu \mathrm{L}$. PCR product was then subjected to Corbett thermal cycler (Corbett Research, Australia). Optimized PCR amplification comprised an initial denaturation step at $42^{\circ} \mathrm{C}$ for $30 \mathrm{~min}$, followed by denaturation at $95^{\circ} \mathrm{C}$ for $10 \mathrm{~min}$, annealing at $95^{\circ} \mathrm{C}$ for $15 \mathrm{sec}$, extension at $50^{\circ} \mathrm{C}$ for $30 \mathrm{sec}$, and final extension step at $72^{\circ} \mathrm{C}$ for $3 \mathrm{sec}$. Melt curves were analysed to check for absence of mispriming. Possibility of genomic DNA influence on the results was eliminated by use of primers. Each experiment was performed three times and all samples were run in triplicates. Expression levels for each gene relative to housekeeping gene, $\beta$-actin, were calculated for all samples using Rotor-Gene (version 1.7, Corbett Research) and Microsoft Excel. Analysis of gene expression data was carried out by $\Delta \Delta \mathrm{CT}$ method of relative quantification as described in [21]. Ratio in untreated cells (negative control) was assigned as 1 .

3.10. Statistical Analysis. Each experiment was conducted three times and determinations were in triplicates. Data were analyzed by analysis of variance (ANOVA) and Bonferroni test using SPSS software (version 20). Statistical significance was fixed at $P<0.05$. Values are shown as mean \pm standard deviation (S.D.).

\section{Results and Discussion}

4.1. Extraction and Fractionation. The yield for petroleum ether extract was $12.9 \mathrm{~g}(10.32 \%), 12 \mathrm{~g}$ (9.6\%) for $\mathrm{MeOH}$ extract, and $9.8 \mathrm{~g}(7.84 \%)$ for ethyl acetate extract from $125 \mathrm{~g}$ of leaf powder. Fractionation of the ethyl acetate extract (10 g) yielded F7 as the highest yield of $2.2 \mathrm{~g}$ (22\%), F6 of $1.8 \mathrm{~g}(18 \%)$, F5, and F4: $1.2 \mathrm{~g}(12 \%)$ each, F3, F2, and F1, $0.88 \mathrm{~g}(8.8 \%), 0.7 \mathrm{~g}$ (7\%), and $6.8 \mathrm{~g}(6.8 \%)$, respectively.

4.2. Antioxidant Activity. The antioxidant activity of crude extracts is shown in Table 1 and fractions isolated from EtOAc crude extract are shown in Table 2. 
TABLE 1: Antioxidant activities of four crude extracts of $P$. minus.

\begin{tabular}{lccc}
\hline Crude extract & $\begin{array}{c}\text { TPC } \\
(\text { mg GAE/g extract })\end{array}$ & $\begin{array}{c}\text { DPPH scavenging } \\
\text { activity }\left(\mathrm{EC}_{50}\right)(\mu \mathrm{g} / \mathrm{mL})\end{array}$ & $\begin{array}{c}\text { FRAP value }(\mu \mathrm{mol} \mathrm{Fe}(\mathrm{II}) / \mathrm{mg} \\
\text { dry weight extract) }\end{array}$ \\
\hline Pet. Ether & $78.2 \pm 3.2^{\mathrm{a}}$ & $745.2 \pm 20.2^{\mathrm{a}}$ & $345.67 \pm 4.9^{\mathrm{a}}$ \\
$\mathrm{MeOH}$ & $128.2 \pm 7.8^{\mathrm{b}}$ & $540 \pm 10.8^{\mathrm{b}}$ & $781.32 \pm 4.2^{\mathrm{b}}$ \\
EtOAc & $227 \pm 4.5^{\mathrm{c}}$ & $120.3 \pm 2.7^{\mathrm{c}}$ & $2435.21 \pm 28.9^{\mathrm{c}}$ \\
Water & $132.3 \pm 10.3^{\mathrm{b}}$ & $472.5 \pm 15.2^{\mathrm{b}}$ & $842.61 \pm 21.3^{\mathrm{b}}$ \\
\hline
\end{tabular}

Values are mean \pm S.D $(n=3)$. Values with different alphabets in the same column are significantly different $(P<0.05$, ANOVA and Bonferroni test $)$. GAE: gallic acid equivalents.

TABLE 2: Antioxidant activities of fractions isolated from EtOAc crude extract of P. minus.

\begin{tabular}{lccc}
\hline EtOAc fractions & $\begin{array}{c}\text { TPC } \\
(\text { mg GAE/g extract })\end{array}$ & $\begin{array}{c}\text { DPPH scavenging } \\
\text { activity }\left(\mathrm{EC}_{50}\right)(\mu \mathrm{g} / \mathrm{mL})\end{array}$ & $\begin{array}{c}\text { FRAP value }(\mu \text { mol Fe (II)/mg } \\
\text { dry weight extract) }\end{array}$ \\
\hline F1 & $\mathrm{ND}$ & $>1 \mathrm{mg} / \mathrm{mL}$ & $\mathrm{ND}$ \\
F2 & $14.2 \pm 3.5^{\mathrm{a}}$ & $568 \pm 8.7^{\mathrm{a}}$ & $147.53 \pm 8.4^{\mathrm{a}}$ \\
F3 & $16.3 \pm 4.2^{\mathrm{a}}$ & $348.6 \pm 5.7^{\mathrm{b}}$ & $187.46 \pm 10.7^{\mathrm{b}}$ \\
F4 & $21.7 \pm 3.1^{\mathrm{b}}$ & $200.2 \pm 2.1^{\mathrm{c}}$ & $224.41 \pm 26.5^{\mathrm{c}}$ \\
F5 & $57.2 \pm 6.8^{\mathrm{c}}$ & $140.3 \pm 3.2^{\mathrm{d}}$ & $270.76 \pm 17.2^{\mathrm{d}}$ \\
F6 & $96 \pm 6.7^{\mathrm{d}}$ & $90.2 \pm 4.5^{\mathrm{e}}$ & $356.84 \pm 10.9^{\mathrm{e}}$ \\
F7 & $113.16 \pm 6.2^{\mathrm{e}}$ & $30.5 \pm 3.2^{\mathrm{f}}$ & $1169.1 \pm 20.3^{\mathrm{f}}$ \\
Trolox & $99 \pm 2.4^{\mathrm{d}}$ & $\mathrm{ND}$ & $\mathrm{ND}$ \\
Chlorogenic acid & $\mathrm{ND}$ & $19.95 \pm 2.8^{\mathrm{g}}$ & $\mathrm{ND}$ \\
Ascorbic acid & $\mathrm{ND}$ & $\mathrm{ND}$ & $3305.67 \pm 51.5^{\mathrm{g}}$ \\
\hline
\end{tabular}

Values are mean \pm S.D $(n=3)$. Values with different alphabets in the same column are significantly different $(P<0.05$, ANOVA and Bonferroni test). GAE: gallic acid equivalents. ND: not determined.

TABLE 3: Qualitative analysis of phytochemicals of P. minus.

\begin{tabular}{lcccc}
\hline \multirow{2}{*}{ Phytochemical test } & \multicolumn{4}{c}{ Extract of P. minus } \\
& Pet. ether & EtOAc & $\mathrm{MeOH}$ & Water \\
\hline Flavonoids & - & +++ & + & + \\
Alkaloids & - & +++ & - & - \\
Saponins & ++ & ++ & - & +++ \\
\hline
\end{tabular}

Remarks: +++: high intensity; ++: moderate intensity; +: less intensity; -: absent.

4.3. Phytochemical Screening. TPC of the four crude extracts was determined from a linear gallic acid standard curve ( $y=$ $\left.0.005 x+0.132, R^{2}=0.982\right)$ (Table 1). There was a significant difference $(P<0.05)$ in TPC among the extracts with EtOAc extract exhibiting the highest TPC. This indicates that EtOAc was the best solvent to extract phenolic components from this plant. Similar findings were reported by [22-24]. Qualitative analysis of $P$. minus crude extracts also pointed to high amounts of flavonoids, a polyphenol group, in EtOAc extract (Table 3). Subsequent fractionation of EtOAc crude extract yielded 7 fractions (Table 2). Of these, F7 had the highest TPC value, higher even than that of Trolox, a vitamin E analogue. Fractionation using solvent elution from nonpolar solvent (hexane) to more polar solvent (EtOAc) yielded fractions with different chemical constituents. TPC content of each of these fractions was significantly smaller than that of crude extract suggesting that the phenolic components were separated based on their polarity. Sum of TPC of these fractions was larger than that of EtOAc crude extract pointing to possible interactions between chemicals in crude extracts which resulted in attenuation of its reducing power which was the main principle of the TPC assay [16].

DPPH assay results were presented as concentration of extract which scavenged $50 \%$ of DPPH radicals $\left(\mathrm{EC}_{50}\right)$. EtOAc extract showed lowest $\mathrm{EC}_{50}$ of $120.3 \pm 2.7 \mu \mathrm{g} / \mathrm{mL}$ in DPPH assay (Table 1). $\mathrm{MeOH}$ and water crude extracts showed large $\mathrm{EC}_{50}$ values while petroleum ether extract showed the weakest DPPH scavenging activity. Of the fractions, $\mathrm{EC}_{50}$ for DPPH scavenging by F7 was the lowest at $30.5 \pm 3.2 \mu \mathrm{g} / \mathrm{mL}$ (Table 2 ). $\mathrm{EC}_{50}$ for F7 was only 1.5 times that of chlorogenic acid which had an $\mathrm{EC}_{50}$ of $20 \pm 2.8 \mu \mathrm{g} / \mathrm{mL}$. Results from DPPH assay showed scavenging activity of the fractions in descending order as F7 $>$ F6 $>$ F5 $>$ F4 $>$ F3 $>$ F2 $>$ F1. DPPH assay results correlated well with TPC $(r=0.904, P<0.01)$. Purification and concentration of polyphenolic compounds must have occurred with increase in polarity of extraction solvents that were used during the fractionation procedures as previously reported $[25,26]$.

FRAP assay determines the reducing power of test compounds. The assay depends on reduction of ferric tripyridyltriazine complex (Fe (III)-TPTZ) to ferrous tripyridyltriazine (Fe (II)-TPTZ) by a reductant at low pH. FRAP value for EtOAc extract was the highest amongst the crude extracts at $2435.21 \pm 28.9 \mu \mathrm{mol} \mathrm{Fe}$ (II)/mg dry weight extract (Table 1). After fractionation, FRAP values of F1 to $\mathrm{F} 7$ were in the range of $147.53 \pm 8.4$ to $1169.1 \pm 20.3 \mu \mathrm{mol} \mathrm{Fe}$ (II)/mg dry weight extract (Table 2). Sum of FRAP values of F1 to F7 was 
TABLE 4: $\mathrm{IC}_{50}$ values of $P$. minus extracts on different cell lines after $72 \mathrm{~h}$ of incubation.

\begin{tabular}{lcccccr}
\hline Crude extract & HepG2 & WRL 68 & HeLA & HCT 116 & MCF-7 & Chang \\
\hline Pet. ether & $>250^{\mathrm{a}}$ & $56.23 \pm 3.2^{\mathrm{c}}$ & $127.21 \pm 3.2^{\mathrm{b}}$ & $145.32 \pm 3.3^{\mathrm{d}}$ & $>250^{\mathrm{a}}$ & $>250^{\mathrm{a}}$ \\
EtOAc & $32.25 \pm 3.72^{\mathrm{b}}$ & $122.38 \pm 20.84^{\mathrm{b}}$ & $63.09 \pm 6.7^{\mathrm{c}}$ & $199.52 \pm 5.2^{\mathrm{b}}$ & $>250^{\mathrm{a}}$ & $285.72 \pm 59.8^{\mathrm{b}}$ \\
MeOH & $>250^{\mathrm{a}}$ & $>250^{\mathrm{a}}$ & $205 \pm 4.3^{\mathrm{d}}$ & $86.3 \pm 3.5^{\mathrm{c}}$ & $>250^{\mathrm{a}}$ & $>250^{\mathrm{a}}$ \\
Water & $>250^{\mathrm{a}}$ & $>250^{\mathrm{a}}$ & $>250^{\mathrm{a}}$ & $>250^{\mathrm{a}}$ & $>250^{\mathrm{a}}$ & $>250^{\mathrm{a}}$ \\
\hline
\end{tabular}

HepG2 cells $\left(2 \times 10^{6} /\right.$ well $)$ were incubated with crude extracts of $P$. minus for $72 \mathrm{~h}$ at $37^{\circ} \mathrm{C}$. Results are mean \pm S.D $(n=3)$. Values with different alphabets in the same column are significantly different $(P<0.05$, ANOVA and Bonferroni test).

$2356 \mu \mathrm{mol} \mathrm{Fe}(\mathrm{II}) / \mathrm{mg}$ dry weight extract. This was not much different from FRAP value of crude EtOAc extract. Each of fractions 1 to 7 possibly contributed to total antioxidant capacity shown by the crude EtOAc extract. Tripathi et al. showed that antioxidant compounds in an extract show synergistic effect in their investigations on effect of crude or total extract and their fractions in inflammation iNOS signaling cascade [27]. FRAP values of $P$. minus fractions were linearly correlated to TPC (FRAP versus TPC, $r=$ $0.83, P<0.05)$. Since EtOAc typically extracts polyphenolic compounds [28], F7 most probably contains polyphenols with high antioxidant capacity since polyphenols act as electron donors to stabilize free radicals [29]. Plant extracts that contained high concentrations of phenolics demonstrate high antioxidant effects in vitro [30]. Vitamin E, tocotrienols, tocopherols, and ascorbic acid may also contribute to antioxidant capacity as well as to the synergistic effect among the compounds [31]. EtOAc crude extract by qualitative analysis showed presence of high amounts of flavonoids which would act as reductants in TPC and FRAP assays and as scavengers in DPPH assay. Since saponins do not contribute to FRAP values [32], water extract of $P$. minus which showed high content of saponins in qualitative assay had low FRAP value when compared to EtOAc extract.

4.4. Antiproliferative Activity. Antiproliferative effects of $P$. minus crude extracts on selected cancer and normal cell lines were determined (Table 4). Of the 4 crude extracts, EtOAc extract had the lowest $\mathrm{IC}_{50}$ of $32.25 \pm 3.72 \mu \mathrm{g} / \mathrm{mL}$ towards HepG2 with little cytotoxicity towards normal embryonic liver cells (WRL68) or normal Chang liver cells. IC $_{50}$ values of EtOAc crude extract towards these latter two normal liver cell lines were $122.38 \pm 20.84$ and $285.72 \pm 59.8 \mu \mathrm{g} / \mathrm{mL}$, respectively. Colon cancer cells (HCT 116) and mammary cancer cells (MCF-7) were not much affected by EtOAc extract although there were moderate effects against cervical cancer cell line (HeLA). $\mathrm{MeOH}$ extract of $P$. minus also showed moderate antiproliferative effects against HCT 116 although it was ineffective against the other cell lines. Petroleum ether extract was cytotoxic in WRL68 with $\mathrm{IC}_{50}$ of $56.23 \pm 3.2 \mu \mathrm{g} / \mathrm{mL}$ but has no antiproliferative effects in cancer cell lines. Crude water extract had no antiproliferative effect on cancer cell lines and no cytotoxicity in normal cell lines $\left(\mathrm{IC}_{50}>250 \mu \mathrm{g} / \mathrm{mL}\right.$ in all cases). This finding of water extract being noncytotoxic is important as it provides evidence that the herb is safe when added to certain Malay foods during their preparation.
TABLE 5: $\mathrm{IC}_{50}$ values of different fractions from EtOAc extract of $P$. minus on HepG2 cell line.

\begin{tabular}{lc}
\hline Fractions & $\mathrm{IC}_{50}(\mu \mathrm{g} / \mathrm{mL})$ \\
\hline F1 & $\mathrm{ND}$ \\
F2 & $52.86 \pm 2.4^{\mathrm{a}}$ \\
F3 & $63.19 \pm 2.64^{\mathrm{b}}$ \\
F4 & $46.12 \pm 6.1^{\mathrm{a}}$ \\
F5 & $65.96 \pm 2.5^{\mathrm{b}}$ \\
F6 & $42.08 \pm 3.22^{\mathrm{a}}$ \\
F7 & $25.75 \pm 1.5^{\mathrm{c}}$ \\
\hline
\end{tabular}

HepG2 cells $\left(2 \times 10^{6} /\right.$ well $)$ were incubated with $P$. minus fractions for $72 \mathrm{~h}$ at $37^{\circ} \mathrm{C}$. Results are mean \pm S.D. $(n=3)$. Values with different alphabets are significantly different $(P<0.05$, ANOVA and Bonferroni test). ND: not determined.

Our data show that EtOAc crude extract has selective antiproliferative effect on HepG2 with little cytotoxicity on normal liver cells. This is important as selectivity of extract towards cancer cells without effect on normal cells is crucial to ensure that nontarget cells are not affected by treatment so as to gain optimal therapeutic effects with minimal adverse effects. Similar views are abundant in the literature $[33,34]$. The bioactive compounds in EtOAc crude extract inhibited proliferation of HepG2 cells. This extract was thus fractionated for further biological investigations on $P$. minus. Fractions of EtOAc extract displayed better antiproliferative activity than the crude extract (Table 5). F7 exhibited the smallest $\mathrm{IC}_{50}$ of $25.75 \pm 1.5 \mu \mathrm{g} / \mathrm{mL}$ towards HepG2 cells compared to the other fractions. F7 also showed the highest antioxidant capacity in TPC, FRAP, and DPPH assays. Qualitative analysis of EtOAc crude extract from which F7 was obtained showed it to be high in flavonoids, alkaloids, and saponins; these groups of compounds most probably contributed to antiproliferative effects of F7. In many reports, flavonoids were shown to selectively kill cancer cells which frequently have higher levels of ROS than normal cells [35]. Consistently elevated levels of ROS activate an adaptive stress response which enables cancer cells to survive in high ROS ambience to maintain cellular viability [36]. Flavonoids are known as effective scavengers of ROS and are able to modulate proteins that are involved in cell proliferation mainly through regulation of the cell cycle [37]. In addition, flavonoids were able to induce apoptotic death in many cancer cells and act as antiangiogenic agents [38]. As example, luteolin, a 


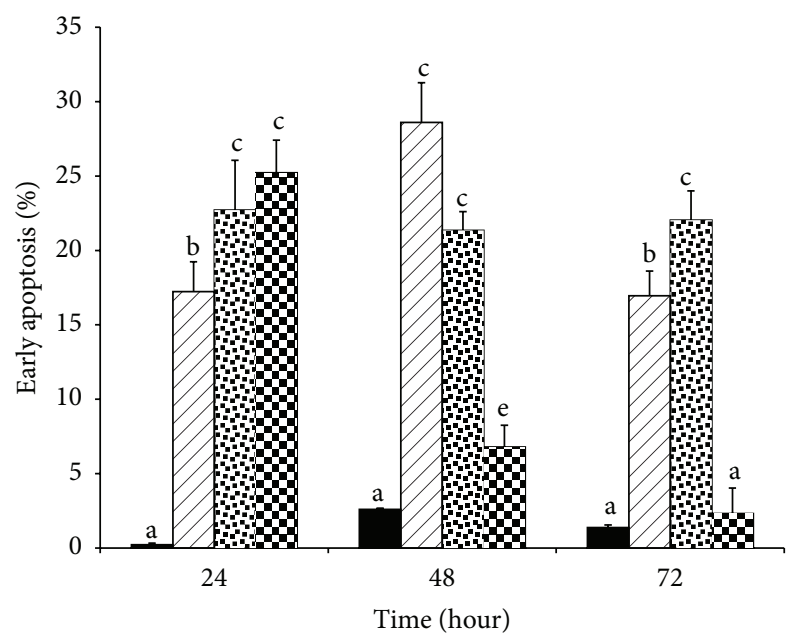

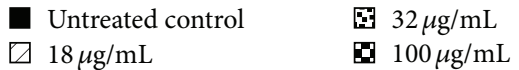

FIGURE 2: Early apoptosis in HepG2 cells exposed to EtOAc crude extract of $P$. minus. HepG2 cells $\left(1 \times 10^{6} /\right.$ well $)$ were incubated with EtOAc crude extract of $P$. minus $(18-100 \mu \mathrm{g} / \mathrm{mL})$ for different periods $(24,48$, and $72 \mathrm{~h})$ at $37^{\circ} \mathrm{C}$. Apoptosis was detected by flow cytometry using annexin-V and FITC. Results are mean \pm S.D. $(n=3)$. Values with different alphabets are significantly different $(P<0.05$, ANOVA and Bonferroni test).

common flavonoid in plants, was found to arrest the cell cycle at $G_{1}$ phase in human gastric, prostate, and melanoma cancer cells and was an apoptotic inducer at both intrinsic and extrinsic pathways. Luteolin exhibited antiangiogenesis effect by suppressing vascular endothelial growth factor and matrix metalloproteases and was antimetastasis through inhibition of tumor necrosis factor and interleukin- 6 which regulate cell migration and metastasis [39]. Besides exhibiting similar mechanisms of action as flavonoids, alkaloids and saponins may also contribute to antiproliferative effects by inducing cell cancer autophagy and antimultidrug resistance and antimitotic effect [40]. Existing data on concomitant use of antioxidant compounds and chemotherapy showed that antioxidant supplementation led to improvement in treatment outcomes, increased survival times, increased tumor response, and reduced toxicity [41]. However, some studies also showed no significant improvements in treatment outcomes that could be attributed to use of insufficient antioxidant doses [42]. Chemotherapeutic drugs like doxorubicin and vinorelbine work via mechanisms that involve induction of apoptosis in cancer cells through ROS-mediated oxidative stress $[43,44]$. For these types of drugs, concomitant supplementation with antioxidants during cancer chemotherapy may lead to diminished anticancer effects. However, no trials have reported significant reductions in treatment efficacy with antioxidant supplementation, suggesting no evidence of antioxidants interfering with chemotherapy $[41,45]$.

4.5. Apoptosis Induction by EtOAc Extract and F7 of P. minus in Hep G2 Cells. Mode of cell death induced by F7 was examined via detection of translocation of phosphatidylserine into

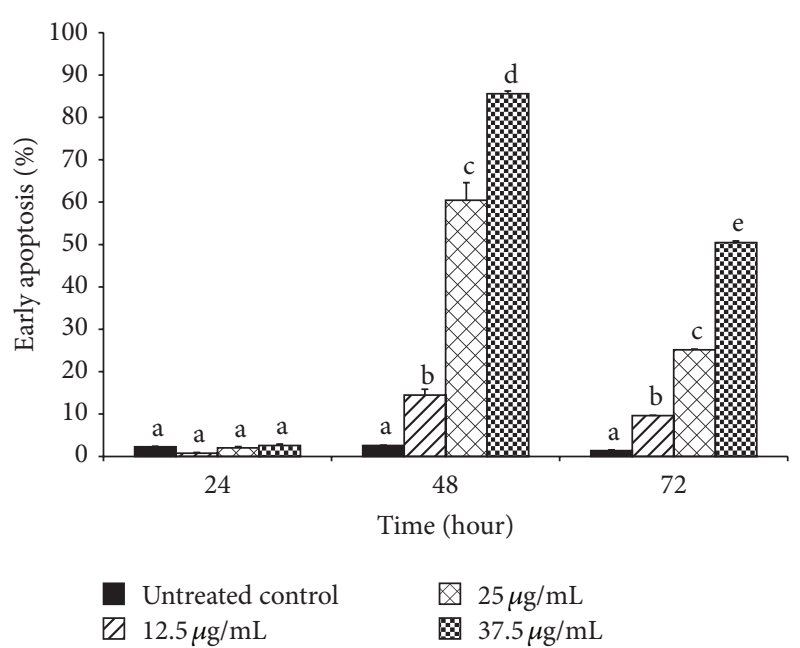

Figure 3: Percentage of HepG2 cells in early apoptosis upon exposure to F7 of $P$. minus. HepG2 cells $\left(1 \times 10^{6} /\right.$ well $)$ were incubated with F7 of $P$. minus $(12.5-37.5 \mu \mathrm{g} / \mathrm{mL})$ for different periods $(24,48$, and $72 \mathrm{~h}$ ) at $37^{\circ} \mathrm{C}$. Apoptosis was detected by flow cytometry using annexin V-FITC. Results are mean \pm S.D $(n=3)$. Values with different alphabets are significantly different $(P<0.05$, ANOVA and Bonferroni test).

outer cell membrane. This is a hallmark event for early apoptosis whereby cancer cells will emit the signal to surrounding macrophages to initiate autophagy [46]. EtOAc crude extract elicited a significant increase in percentage of HepG2 cells in early apoptosis (Figure 2). Lowest concentration of EtOAc crude extract $(18 \mu \mathrm{g} / \mathrm{mL})$ showed time-dependent increase in percentage of cells undergoing early apoptosis. Exposure to $24 \mathrm{~h}$ produced about $20 \%$ increase. After $48 \mathrm{~h}$ of exposure, maximal increase to nearly $30 \%$ was seen, but after $72 \mathrm{~h}$, percentage of cells in early apoptosis had dropped significantly to less than $20 \%$. A higher concentration $(32 \mu \mathrm{g} / \mathrm{mL})$ of EtOAc crude extract increased percentage of cells in early apoptosis by between 20 and $25 \%$ starting from $24 \mathrm{~h}$ of incubation; however no further increase was seen at longer incubation times. Highest concentration of EtOAc crude extract $(100 \mu \mathrm{g} / \mathrm{mL})$ produced maximal increase in percentage of cells in early apoptosis by $24 \mathrm{~h}$. By $48 \mathrm{~h}$, the percentage had dropped significantly to about $5 \%$. A further significant decrease in percentage of cells in early apoptosis was seen at $72 \mathrm{~h}$. Treatment of HepG2 cells with F7 also produced similar effects (Figure 3). A shorter incubation period of $24 \mathrm{~h}$ with F7 $(12.5-37.5 \mu \mathrm{g} / \mathrm{mL})$ did not affect the cell population in early apoptosis. At $48 \mathrm{~h}$, a concentrationdependent increase in percentage of cells in early apoptosis was seen. Highest concentration of F7 $(37.5 \mu \mathrm{g} / \mathrm{mL})$ induced nearly $85 \%$ of cells to undergo apoptosis. This effect was inversely dependent on incubation time as percentage of cells undergoing early apoptosis decreased to approximately $50 \%$ after $72 \mathrm{~h}$. With a longer period of incubation, HepG2 cells shifted from a situation of having maximum viability to entering early apoptosis and then to late-stage apoptosis and necrosis (Figure 4). Population of cells undergoing apoptosis upon exposure to $\mathrm{F} 7$ at its $\mathrm{IC}_{50}$, at $72 \mathrm{~h}$, was smaller than at 
TABLE 6: Gene name, base pair (b.p) size, and forward and reverse primer sequences that were used in the real time PCR experiment.

\begin{tabular}{lccc}
\hline Gene name & b.p & Forward primer & Reverse primer \\
\hline NM_031142.2 $($ Actb $)$ & 97 & ATGGTGGGTATGGGTCAG & CAATGCCGTGTTCAATGG \\
NM_000633.2 $(B c l 2)$ & 177 & CCACCAAGAAAGCAGGAAACC & GGCAGGATAGCAGCACAGG \\
NM_032991.2 $($ Casp3 $)$ & 159 & CTGGACTGTGGCATTGAGAC & ACAAAGCGACTGGATGAACC \\
NM_00141980.1 $(p 53)$ & 113 & AGAACGAGGAGACGGTAATAGTG & CAATGACCTGACTGATGGAACC \\
NM_004324.3 $($ Bax $)$ & 110 & CAGATGTGGTCTATAATGC & CTAATCAAGTCAAGGTCAC \\
\hline
\end{tabular}

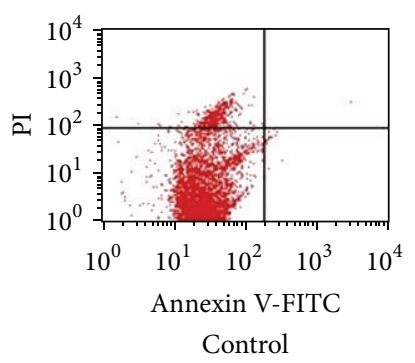

(a)

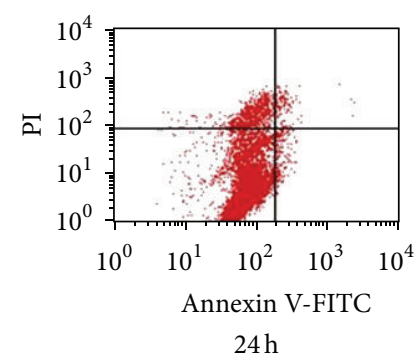

(b)

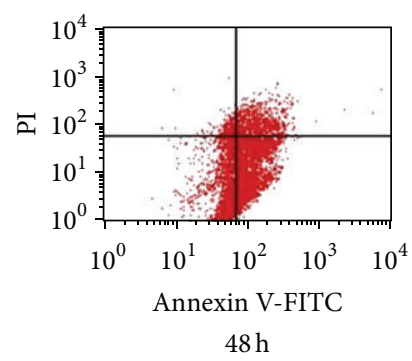

(c)

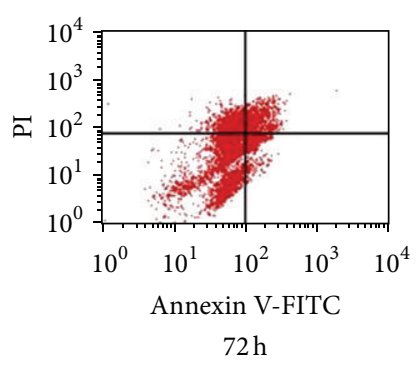

(d)

Figure 4: Histogram of annexin-V and FITC/PI flow cytometry of HepG2 cells exposed to F7. HepG2 cells $\left(1 \times 10^{6} /\right.$ well $)$ were incubated with F7 of $P$. minus $\left(25 \mu \mathrm{g} / \mathrm{mL}\right.$, equivalent to $\mathrm{IC}_{50}$ ) or (a) control for (b) $24,(\mathrm{c}) 48$ and (d) $72 \mathrm{~h}$ at $37^{\circ} \mathrm{C}$. Lower left quadrant in each panel represents viable cells which excluded PI and were negative for annexin V-FITC binding. Upper right quadrant contains nonviable, necrotic cells or late stage apoptotic cells, positive for annexin V-FITC/PI uptake. Lower right quadrant contains early apoptotic cells, annexin V-FITC positive and PI negative. One experiment is representative of three independent experiments.

$48 \mathrm{~h}$. Conversely, late apoptotic/necrotic cell population was higher at $72 \mathrm{~h}$ than at $48 \mathrm{~h}$. These results show that at $72 \mathrm{~h}$, F7 had induced necrotic cell death rather than apoptotic cell death. A range of stimuli such as radiation, hypoxia, heat, and cytotoxic compounds induce apoptosis at low concentrations but higher concentrations of these stimuli can result in necrosis [47]. Three types of cellular response to plant extracts have been proposed [48]. Mild exposure may cause mild oxidative stress that ignites cellular antioxidant defense systems; exposure to moderate to higher concentrations may gradually overwhelm antioxidant defense systems to induce apoptosis, while exposure to even higher concentrations for long periods may quickly overwhelm antioxidant defenses to stimulate prooxidative effects leading to cellular damage via necrosis. Two factors that transform an ongoing apoptotic process to a necrotic process are the availability of intracellular ATP and of caspases [49]. Extended exposure of cells to plant extract may cause loss of mitochondrial membrane potential and may promote release of cytochrome$c$ leading to distortion of electron transport and inhibition of Krebs cycle [50]. This will finally cause depletion in ATP and rapid generation of ROS which can both cause cell death without involvement of caspases [51]. Proapoptotic activity of apoptosome is dependent on availability of ATP; thus reduction of energy would cause a greater proportion of cells to undergo necrosis rather than apoptosis [52]. DNA fragmentation during apoptosis of HepG2 cells that were treated with F7 $(12.5-37.5 \mu \mathrm{g} / \mathrm{mL})$ for $48 \mathrm{~h}$ was visualized via TUNEL assay using fluorescent confocal microscopy (Figure 5). Cells that were stained red were viable while bright green stains indicated apoptotic cell bodies with DNA fragmentation.

4.6. Expression of Genes Related to Apoptosis. Molecular mechanism of apoptosis was investigated using RT-PCR by examining expression of key apoptotic-related genes. Primer sequences of the genes are shown in Table 6. Bcl-2 gene is an antiapoptotic gene; overexpression of this gene would prevent apoptosis while Bax gene is a proapoptotic gene working oppositely. P53 and caspase-3 genes are vital in executing the apoptosis process in cells. Expression of Bax, Bcl-2, p53, and caspase-3 genes in HepG2 cells that were treated with F7 $(12.5-37.5 \mu \mathrm{g} / \mathrm{mL})$ for $48 \mathrm{~h}$ is shown in Figure 6. F7 induced a concentration-dependent increase in Bax expression. Compared to control untreated cell, mRNA expression of Bax was significantly elevated by about 3-fold at highest concentration of F7 $(37.5 \mu \mathrm{g} / \mathrm{mL})$. The two lower concentrations of F7 produced about 2-2.5-fold increase in Bax expression. Similar concentration-dependent increase in expression levels of caspase- 3 and $p 53$ genes was seen in F7-treated cells. Lowest concentration of F7 significantly increased caspase- 3 expression from control. A significantly greater increase in caspase- 3 expression by about 1.8 -fold was elicited by the highest concentration of F7 used. Expression of $p 53$ gene was significantly increased from control by lowest concentration of F7. Maximal increase in $p 53$ gene expression by about 2-fold was elicited by middle concentration of F7 $(25 \mu \mathrm{g} / \mathrm{mL})$ as no further increase was seen at $37.5 \mu \mathrm{g} / \mathrm{mL}$. In contrast, expression of antiapoptotic gene, $\mathrm{Bcl}$-2, was inhibited in concentration-dependent manner by F7. Highest 


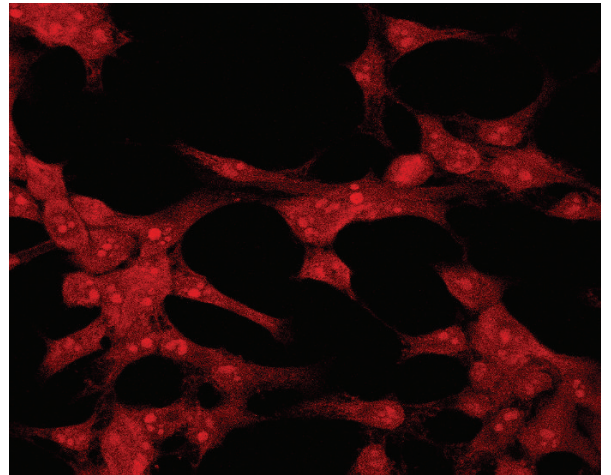

Untreated control

(a)

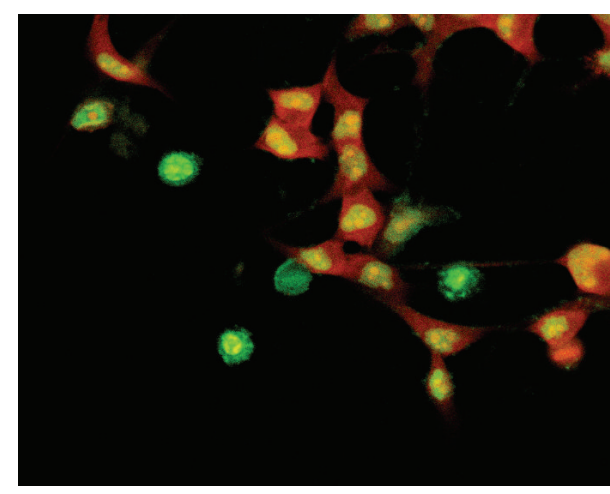

$25 \mu \mathrm{g} / \mathrm{mL}$

(c)

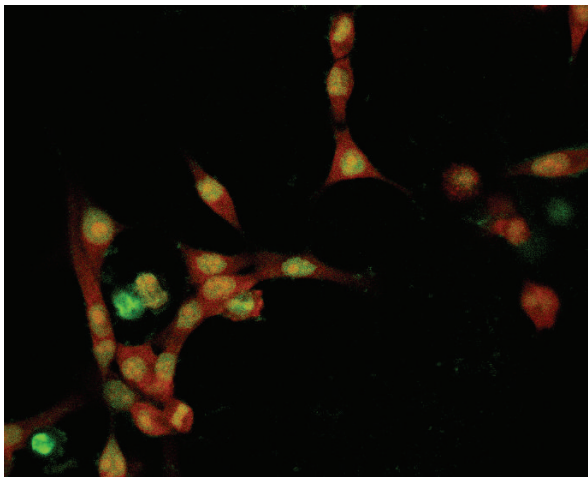

$12.5 \mu \mathrm{g} / \mathrm{mL}$

(b)

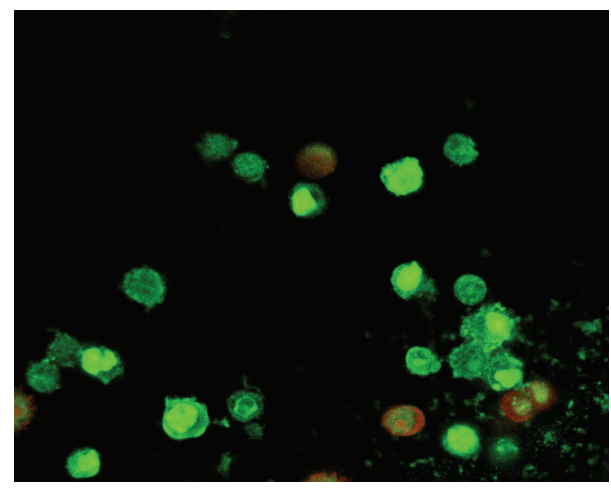

$37.5 \mu \mathrm{g} / \mathrm{mL}$

(d)

FIGURE 5: Fluorescence confocal imaging of TUNEL positive staining in HepG2 cells exposed to F7 at 48 h. HepG2 cells $\left(0.5 \times 10^{6} /\right.$ well $)$ were treated with F7 of $P$. minus $(12.5-37.5 \mu \mathrm{g} / \mathrm{mL})$ for $48 \mathrm{~h}$ at $37^{\circ} \mathrm{C}$. Red stain shows viable, healthy cells while intense green stain indicates apoptotic cell with DNA fragmentation. One experiment is representative of three independent experiments.

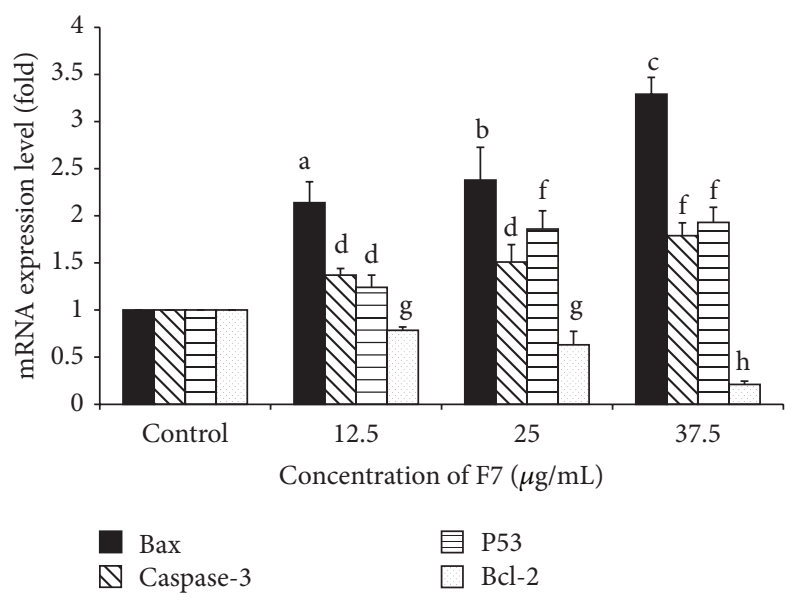

FIGURE 6: Effect of F7 on expression levels of apoptotic-related genes in HepG2 cells. HepG2 cells $\left(1 \times 10^{6} /\right.$ well $)$ were incubated with F7 of $P$. minus $(12.5-37.5 \mu \mathrm{g} / \mathrm{mL})$ for $48 \mathrm{~h}$ at $37^{\circ} \mathrm{C}$. Results are mean \pm S.D $(n=3)$. Values with different alphabets are significantly different $(P<0.05$, ANOVA and Bonferroni test). 

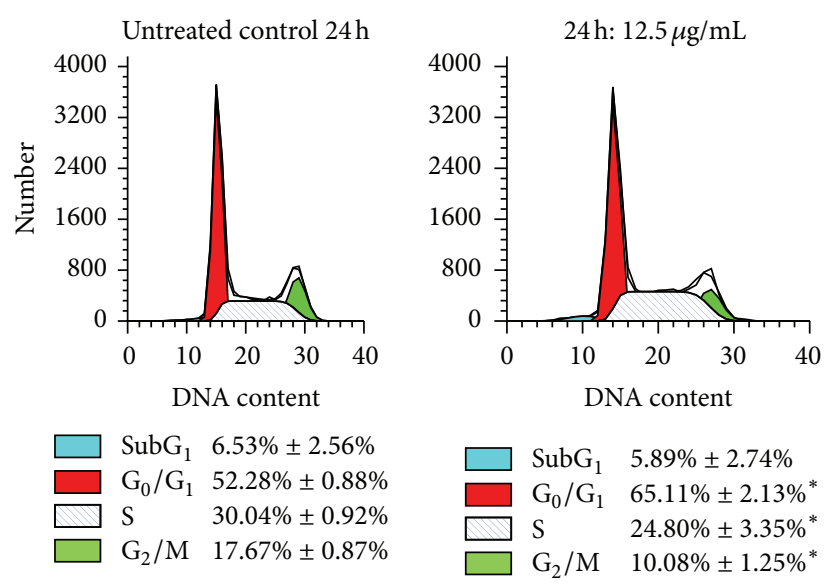

(a)
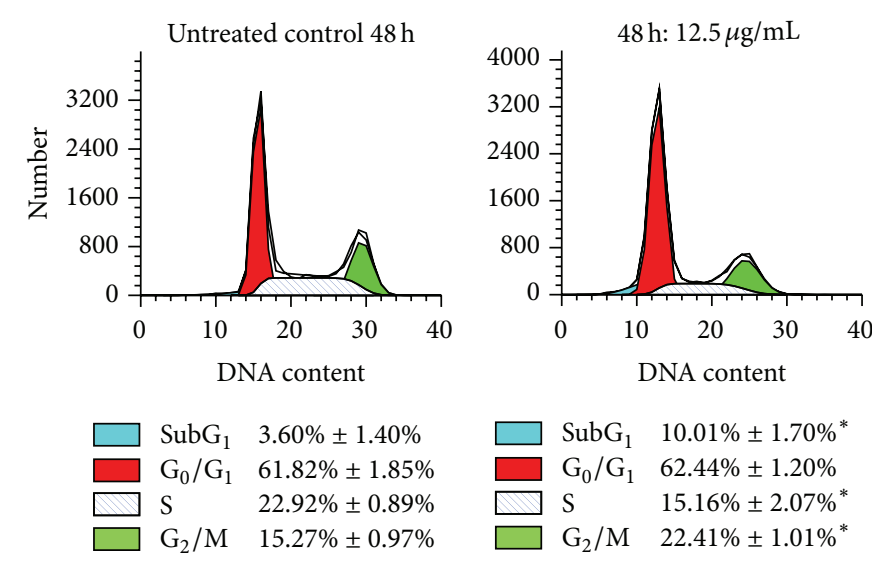
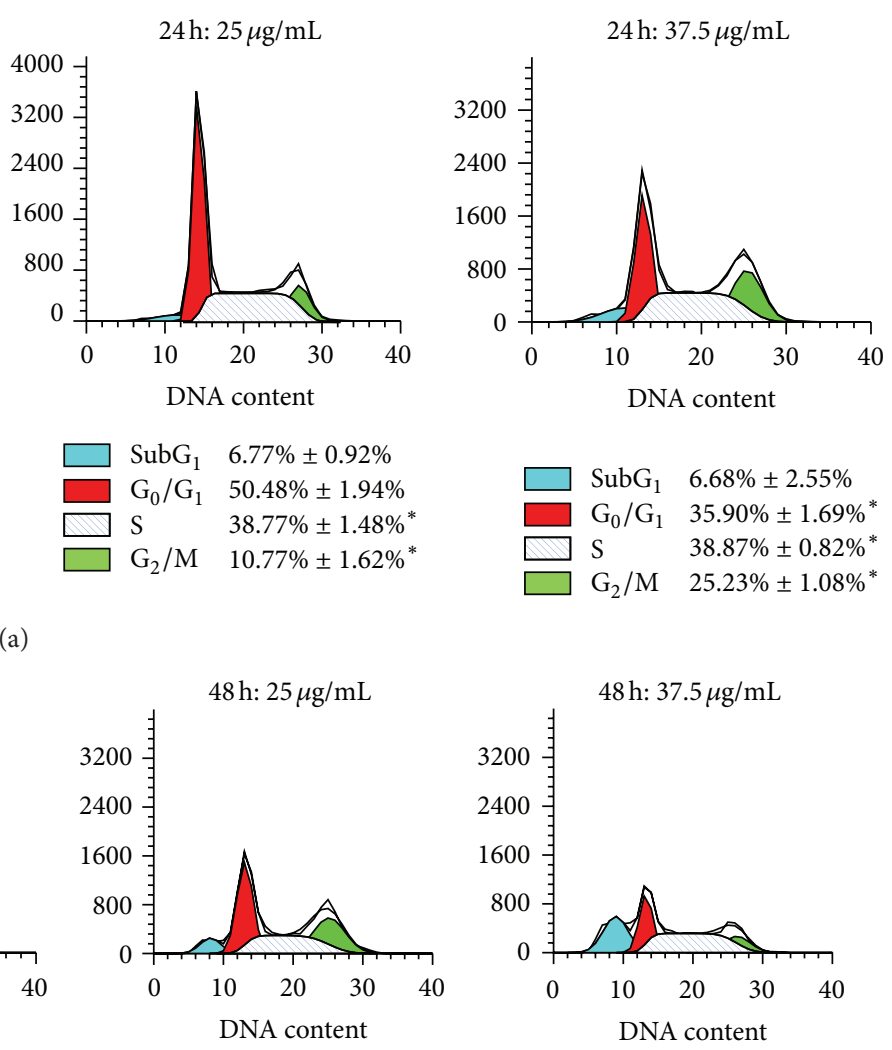

$\mathrm{SubG}_{1} \quad 5.28 \% \pm 2.36 \%$ $\mathrm{G}_{0} / \mathrm{G}_{1} 38.58 \% \pm 1.10 \%{ }^{*}$ $\mathrm{S} \quad 34.47 \% \pm 1.20 \%{ }^{*}$ $\mathrm{G}_{2} / \mathrm{M} \quad 26.94 \% \pm 0.64 \%^{*}$
$\mathrm{SubG}_{1} \quad 25.34 \% \pm 1.20 \%$ * $\mathrm{G}_{0} / \mathrm{G}_{1} \quad 30.37 \% \pm 0.28 \%{ }^{*}$ $\mathrm{S} \quad 52.59 \% \pm 0.33 \%{ }^{*}$ $\mathrm{G}_{2} / \mathrm{M} \quad 17.03 \% \pm 0.49 \%$ *

(b)

FIGURE 7: Effect of F7 of $P$. minus on cell cycle progression in HepG2 cells. Cells $\left(1 \times 10^{6} /\right.$ well) were treated with F7 (12.5-37.5 $\left.\mu \mathrm{g} / \mathrm{mL}\right)$ for (top lane) $24 \mathrm{~h}$ or (bottom lane) $48 \mathrm{~h}$ at $37^{\circ} \mathrm{C}$. Data are representative of three independent experiments. ${ }^{*}$ Significantly different from untreated control cells $(P<0.05$, ANOVA and Bonferroni test).

concentration of F7 elicited maximal inhibition in $\mathrm{Bcl}-2$ expression. Ratio of $\mathrm{Bax} / \mathrm{Bcl}-2$ is crucial at determining susceptibility of cells to death signals [53]. Our results showed F7 induced apoptosis via upregulation of $\mathrm{Bax}, \mathrm{p53}$, and caspase-3 genes and downregulation of $\mathrm{Bcl}-2$ gene. Activation of p53 stimulates release of cytochrome-c from mitochondria [54]. Consequently, apoptosome complex is formed to further initiate effector caspases, including caspase3 , to execute the apoptosis process. Release of mitochondria apoptogenic factors is controlled by $\mathrm{Bax}$ and $\mathrm{Bcl}-2$ genes which either induced or suppress permeabilization of outer mitochondrial membrane [55]. Similar observations were reported in determination of antiproliferative effect of Juglan regia L. by assessment of apoptotic related genes [56].

4.7. Cell Cycle Arrest by F7. Treatment of HepG2 cells with F7 $(12.5,25$, and $37.5 \mu \mathrm{g} / \mathrm{mL})$ for 24 and $48 \mathrm{~h}$ resulted in significant accumulation of cells at S-phase as compared to control untreated cells (Figure 7). The effect was concentrationand time-dependent. After $24 \mathrm{~h}$ of incubation with 25 or $37.5 \mu \mathrm{g} / \mathrm{mL}$ F7, cell population at S-phase was increased compared to control while $\mathrm{G}_{2} / \mathrm{M}$ cell population was increased by the highest concentration of F7. This showed that F7 delayed cell progression through $S$-phase, earlier than $G_{2} / M$ phase, thus restricting cells from entering $G_{0} / G_{1}$ phase. Sub- $G_{1}$ cell population after treatment with $\mathrm{F} 7$ at $24 \mathrm{~h}$ was not altered. Following $48 \mathrm{~h}$ of incubation, highest concentration of F7 increased Sub-G $\mathrm{G}_{1}$ and S-phase populations to approximately $25.34 \pm 1.20 \%$ and $52.59 \pm 0.33 \%$, respectively, while $\mathrm{G}_{2} / \mathrm{M}$ phase was decreased to $17.03 \pm 0.49 \%$. Sub-G $G_{1}$ phase is a hallmark of apoptosis [57]; therefore these findings are consistent with flow cytometry measurements of apoptosis in HepG2 cells treated with F7. p53 also plays an important role in executing cell cycle arrest [58]. During S-phase, cellular DNA is replicated precisely and accurately to prevent genetic abnormalities which could lead to mutations or cell death [59] and $p 53$ is responsible for regulation of certain proteins which are related to cell cycle checkpoint.

\section{Conclusion}

In summary, $P$. minus as ethyl acetate crude extract or its fraction, F7, showed high antioxidant capacity and selective antiproliferative activity against HepG2 cells. The high 
antioxidant capacity of this herb is probably attributed to its polyphenolic content. Antiproliferative effect of F7 was directly correlated to its antioxidant capacity. Flow cytometry analyses and gene expression studies in F7-exposed HepG2 cells provided evidence that F7 induced apoptosis in timeand concentration-dependent manner through upregulation of proapoptotic genes and downregulation of antiapoptotic gene. F7 was antiproliferative towards HepG2 cells via inhibition of the cell cycle at S-phase. Continuing work to identify the compounds in F7 that are responsible for these activities is in progress in our laboratory. We are also looking at effects of F7 on a cancer model in vivo.

\section{Conflict of Interests}

The authors declare that there is no conflict of interests.

\section{Acknowledgments}

This work was supported by MOSTI 100-IRDC/BIOTEK 16/6/2(6/2006) through a research Grant held by Universiti Teknologi MARA. Mohd Alfazari Mohd Ghazali is supported by a fellowship from USM. The authors wish to thank Faculty of Pharmacy, UiTM, for support and facilities.

\section{References}

[1] J. M. Brown and L. D. Attardi, "The role of apoptosis in cancer development and treatment response," Nature Reviews Cancer, vol. 5, no. 3, pp. 231-237, 2005.

[2] V. Jendrossek, "The intrinsic apoptosis pathways as a target in anticancer therapy," Current Pharmaceutical Biotechnology, vol. 13, no. 8, pp. 1426-1438, 2012.

[3] G. Waris and H. Ahsan, "Reactive oxygen species: role in the development of cancer and various chronic conditions," Journal of Carcinogenesis, vol. 5, article 14, 2006.

[4] U. Gawlik-Dziki, M. Swieca, M. Sulkowski, D. Dziki, B. Baraniak, and J. Czyz, "Antioxidant and anticancer activities of Chenopodium quinoa leaves extracts-in vitro study," Food and Chemical Toxicology, vol. 57, pp. 154-160, 2013.

[5] M. Maizura, A. Aminah, and W. M. W. Aida, "Total phenolic content and antioxidant activity of kesum (Polygonum minus), ginger (Zingiber officinale) and turmeric (Curcuma longa) extract," International Food Research Journal, vol. 18, no. 2, p. 529, 2011.

[6] A. A. Azlim Almey, C. Ahmed Jalal Khan, I. Syed Zahir, K. Mustapha Suleiman, M. R. Aisyah, and K. Kamarul Rahim, "Total phenolic content and primary antioxidant activity of methanolic and ethanolic extracts of aromatic plants' leaves," International Food Research Journal, vol. 17, no. 4, pp. 1077-1084, 2010.

[7] Y. Sumazian, A. Syahida, M. Hakiman, and M. Maziah, "Antioxidant activities, flavonoids, ascorbic acid and phenolic contents of Malaysian vegetables," Journal of Medicinal Plant Research, vol. 4, no. 10, pp. 881-890, 2010.

[8] N. Huda-Faujan, A. Noriham, A. S. Norrakiah, and A. S. Babji, "Antioxidant activity of plants methanolic extracts containing phenolic compounds," African Journal of Biotechnology, vol. 8, no. 3, pp. 484-489, 2009.
[9] N. Huda-Faujan, A. Noriham, A. S. Norrakiah, and A. S. Babji, "Antioxidative activities of water extracts of some Malaysian herbs," ASEAN Food Journal, vol. 14, no. 1, pp. 61-68, 2007.

[10] S. W. Qader, M. A. Abdulla, L. S. Chua, H. M. Sirat, and S. Hamdan, "Pharmacological mechanisms underlying gastroprotective activities of the fractions obtained from Polygonum minus in sprague dawley rats," International Journal of Molecular Sciences, vol. 13, no. 2, pp. 1481-1496, 2012.

[11] S. Q. Wasman, A. A. Mahmood, H. Salehhuddin, A. A. Zahra, and I. Salmah, "Cytoprotective activities of Polygonum minus aqueous leaf extract on ethanol-induced gastric ulcer in rats," Journal of Medicinal Plant Research, vol. 4, no. 24, pp. 26582665, 2010

[12] M. M. Mackeen, A. M. Ali, S. H. El-Sharkawy et al., "Antimicrobial and cytotoxic properties of some Malaysian traditional vegetables (ULAM)," Pharmaceutical Biology, vol. 35, no. 3, pp. 174-178, 1997.

[13] S. W. Qader, M. A. Abdulla, L. S. Chua, N. Najim, M. M. Zain, and S. Hamdan, "Antioxidant, total phenolic content and cytotoxicity evaluation of selected Malaysian plants," Molecules, vol. 16, no. 4, pp. 3433-3443, 2011.

[14] Y. K. Ming, N. B. T. Zulkawi, C. Vandana Kotak, and Y. K. Choudhary, "Acute and sub-acute oral toxicity of Polygonum minus aqueous extract (biotropics PM101) in wistar rats," International Journal of Pharmacy and Pharmaceutical Sciences, vol. 5, no. 2, pp. 120-124, 2013.

[15] Z. A. Zakaria, A. M. Mohamed, N. S. M. Jamil et al., "In vitro cytotoxic and antioxidant properties of the aqueous, chloroform and methanol extracts of dicranopteris linearis leaves," African Journal of Biotechnology, vol. 10, no. 2, pp. 273-282, 2011.

[16] M. H. Johnson and E. Gonzalez de Mejia, "Comparison of chemical composition and antioxidant capacity of commercially available blueberry and blackberry wines in Illinois," Journal of Food Science, vol. 77, no. 1, pp. C141-C148, 2012.

[17] S. Gorinstein, O. Martin-Belloso, E. Katrich et al., "Comparison of the contents of the main biochemical compounds and the antioxidant activity of some Spanish olive oils as determined by four different radical scavenging tests," Journal of Nutritional Biochemistry, vol. 14, no. 3, pp. 154-159, 2003.

[18] O. Erel, "A novel automated direct measurement method for total antioxidant capacity using a new generation, more stable ABTS radical cation," Clinical Biochemistry, vol. 37, no. 4, pp. 277-285, 2004.

[19] M. Carvalho, G. Hawksworth, N. Milhazes et al., "Role of metabolites in MDMA (ecstasy)-induced nephrotoxicity: an in vitro study using rat and human renal proximal tubular cells," Archives of Toxicology, vol. 76, no. 10, pp. 581-588, 2002.

[20] N. Armania, L. S. Yazan, S. N. Musa et al., "Dillenia suffruticosa exhibited antioxidant and cytotoxic activity through induction of apoptosis and G2/M cell cycle arrest," Journal of Ethnopharmacology, vol. 146, no. 2, pp. 525-535, 2013.

[21] J. Nestorov, G. Matic, I. Elakovic, and N. Tanic, "Gene expression studies: How to obtain accurate and reliable data by quantitative real-time RT PCR," Journal of Medical Biochemistry, vol. 32, no. 4, pp. 325-338, 2013.

[22] K. S. Sim, A. M. Sri Nurestri, and A. W. Norhanom, "Phenolic content and antioxidant activity of Pereskia grandifolia Haw. (Cactaceae) extracts," Pharmacognosy Magazine, vol. 6, no. 23, pp. 248-254, 2010.

[23] F. Al-Juhaimi, C. Saglam, and M. M. Ozcan, "Antioxidant properties and total phenolic content of two solvent extraction 
extracts of some plants belong to labiatae family," Asian Journal of Chemistry, vol. 25, no. 6, pp. 3011-3013, 2013.

[24] W. Kusirisin, S. Srichairatanakool, P. Lerttrakarnnon et al., "Antioxidative activity, polyphenolic content and anti-glycation effect of some Thai medicinal plants traditionally used in diabetic patients," Medicinal Chemistry, vol. 5, no. 2, pp. 139-147, 2009.

[25] S. Sannigrahi, U. K. Mazuder, D. K. Pal, S. Parida, and S. Jain, "Antioxidant potential of crude extract and different fractions of Enhydra fluctuans Lour," Iranian Journal of Pharmaceutical Research, vol. 9, no. 1, pp. 75-82, 2010.

[26] N. Grujic, Z. Lepojevic, B. Srdjenovic, J. Vladic, and J. Sudji, "Effects of different extraction methods and conditions on the phenolic composition of mate tea extracts," Molecules, vol. 17, no. 3, pp. 2518-2528, 2012.

[27] Y. B. Tripathi, A. P. Chaturvedi, and N. Pandey, "Effect of Nigella sativa seeds extracts on iNOS through antioxidant potential only: crude/total extract as molecular therapy drug," Indian Journal of Experimental Biology, vol. 50, no. 6, pp. 413-418, 2012.

[28] C.-Y. Liu, Y.-C. Lin, J.-S. Deng, J.-C. Liao, W.-H. Peng, and G.J. Huang, "Antioxidant, anti-inflammatory, and antiproliferative activities of Taxillus sutchuenensis," American Journal of Chinese Medicine, vol. 40, no. 2, pp. 335-348, 2012.

[29] K. N. Prasad, L. Y. Chew, H. E. Khoo, K. W. Kong, A. Azlan, and A. Ismail, "Antioxidant capacities of peel, pulp, and seed fractions of Canarium odontophyllum Miq. fruit," Journal of Biomedicine and Biotechnology, vol. 2010, Article ID 871379, 8 pages, 2010.

[30] S. Shukla, A. Mehta, P. Mehta, and V. K. Bajpai, "Antioxidant ability and total phenolic content of aqueous leaf extract of Stevia rebaudiana Bert," Experimental and Toxicologic Pathology, vol. 64, no. 7-8, pp. 807-811, 2012.

[31] N. Babbar, H. S. Oberoi, D. S. Uppal, and R. T. Patil, “Total phenolic content and antioxidant capacity of extracts obtained from six important fruit residues," Food Research International, vol. 44, no. 1, pp. 391-396, 2011.

[32] B. B. Misra and S. Dey, "Comparative phytochemical analysis and antibacterial efficacy of in vitro and in vivo extracts from East Indian sandalwood tree (Santalum album L.)," Letters in Applied Microbiology, vol. 55, no. 6, pp. 476-486, 2012.

[33] R. Hafidh, A. Abdulamir, F. Bakar, F. Jalilian, F. Abas, and Z. Sekawi, "Novel molecular, cytotoxical, and immunological study on promising and selective anticancer activity of Mung bean sprouts," BMC Complementary and Alternative Medicine, vol. 12, article 208, 2012.

[34] M. Paydar, Y. L. Wong, B. A. Moharam, W. F. Wong, and C. Y. Looi, "In vitro anti-oxidant and anti-cancer activity of methanolic extract from Sanchezia speciosa leaves," Pakistan Journal of Biological Sciences, vol. 16, no. 20, pp. 1212-1215, 2013.

[35] T. P. Szatrowski and C. F. Nathan, "Production of large amounts of hydrogen peroxide by human tumor cells," Cancer Research, vol. 51, no. 3, pp. 794-798, 1991.

[36] L. Gibellini, M. Pinti, M. Nasi et al., "Interfering with ROS metabolism in cancer cells: the potential role of quercetin," Cancers, vol. 2, no. 2, pp. 1288-1311, 2010.

[37] K. Bishayee, S. Ghosh, A. Mukherjee, R. Sadhukhan, J. Mondal, and A. R. Khuda-Bukhsh, "Quercetin induces cytochrome-c release and ROS accumulation to promote apoptosis and arrest the cell cycle in G2/M, in cervical carcinoma: signal cascade and drug-DNA interaction," Cell Proliferation, vol. 46, no. 2, pp.153$163,2013$.
[38] H. Luo, G. O. Rankin, L. Liu, M. K. Daddysman, B.-H. Jiang, and Y. C. Chen, "Kaempferol inhibits angiogenesis and VEGF expression through both HIF dependent and independent pathways in human ovarian cancer cells," Nutrition and Cancer, vol. 61, no. 4, pp. 554-563, 2009.

[39] Y. Lin, R. Shi, X. Wang, and H.-M. Shen, "Luteolin, a flavonoid with potential for cancer prevention and therapy," Current Cancer Drug Targets, vol. 8, no. 7, pp. 634-646, 2008.

[40] C. V. Rao, C. D. Kurkjian, and H. Y. Yamada, "Mitosis-targeting natural products for cancer prevention and therapy," Current Drug Targets, vol. 13, no. 14, pp. 1820-1830, 2012.

[41] C. B. Simone II, N. L. Simone, V. Simone, and C. B. Simone, "Antioxidants and other nutrients do not interfere with chemotherapy or radiation therapy and can increase kill and increase survival, part 1," Alternative Therapies in Health and Medicine, vol. 13, no. 1, pp. 22-28, 2007.

[42] A. K. Pathak, M. Bhutani, R. Guleria et al., "Chemotherapy alone vs. chemotherapy plus high dose multiple antioxidants in patients with advanced non small cell lung cancer," Journal of the American College of Nutrition, vol. 24, no. 1, pp. 16-21, 2005.

[43] W.-H. Chiu, S.-J. Luo, C.-L. Chen et al., "Vinca alkaloids cause aberrant ROS-mediated JNK activation, Mcl-1 downregulation, DNA damage, mitochondrial dysfunction, and apoptosis in lung adenocarcinoma cells," Biochemical Pharmacology, vol. 83, no. 9, pp. 1159-1171, 2012.

[44] A. Rogalska, A. Gajek, M. Szwed, Z. Jóźwiak, and A. Marczak, "The role of reactive oxygen species in WP 631-induced death of human ovarian cancer cells: a comparison with the effect of doxorubicin," Toxicology in Vitro, vol. 25, no. 8, pp. 1712-1720, 2011.

[45] K. I. Block, A. C. Koch, M. N. Mead, P. K. Tothy, R. A. Newman, and C. Gyllenhaal, "Impact of antioxidant supplementation on chemotherapeutic efficacy: a systematic review of the evidence from randomized controlled trials," Cancer Treatment Reviews, vol. 33, no. 5, pp. 407-418, 2007.

[46] K. Balasubramanian, B. Mirnikjoo, and A. J. Schroit, "Regulated externalization of phosphatidylserine at the cell surface: implications for apoptosis," The Journal of Biological Chemistry, vol. 282, no. 25, pp. 18357-18364, 2007.

[47] S. Elmore, "Apoptosis: a review of programmed cell death," Toxicologic Pathology, vol. 35, no. 4, pp. 495-516, 2007.

[48] H. Babich, A. G. Schuck, J. H. Weisburg, and H. L. Zuckerbraun, "Research strategies in the study of the pro-oxidant nature of polyphenol nutraceuticals," Journal of Toxicology, vol. 2011, Article ID 467305, 12 pages, 2011.

[49] M. Leist, B. Single, A. F. Castoldi, S. Kühnle, and P. Nicotera, "Intracellular adenosine triphosphate (ATP) concentration: a switch in the decision between apoptosis and necrosis," The Journal of Experimental Medicine, vol. 185, no. 8, pp. 1481-1486, 1997.

[50] J.-L. Vayssière, P. X. Petit, Y. Risler, and B. Mignotte, “Commitment to apoptosis is associated with changes in mitochondrial biogenesis and activity in cell lines conditionally immortalized with simian virus 40," Proceedings of the National Academy of Sciences of the United States of America, vol. 91, no. 24, pp. 1175211756, 1994.

[51] C. J. Zeiss, "The apoptosis-necrosis continuum: insights from genetically altered mice," Veterinary Pathology, vol. 40, no. 5, pp. 481-495, 2003.

[52] Y. Eguchi, A. Srinivasan, K. J. Tomaselli, S. Shimizu, and Y. Tsujimoto, "ATP-dependent steps in apoptotic signal transduction," Cancer Research, vol. 59, no. 9, pp. 2174-2181, 1999. 
[53] I. Marzo and J. Naval, "Bcl-2 family members as molecular targets in cancer therapy," Biochemical Pharmacology, vol. 76, no. 8, pp. 939-946, 2008.

[54] V. Gogvadze, S. Orrenius, and B. Zhivotovsky, "Multiple pathways of cytochrome c release from mitochondria in apoptosis," Biochimica et Biophysica Acta-Bioenergetics, vol. 1757, no. 5-6, pp. 639-647, 2006.

[55] M. Schuler and D. R. Green, "Mechanisms of p53-dependent apoptosis," Biochemical Society Transactions, vol. 29, no. 6, pp. 684-688, 2001.

[56] A. A. Alshatwi, T. N. Hasan, G. Shafi et al., "Validation of the antiproliferative effects of organic extracts from the green husk of Juglans regia L. on PC-3 human prostate cancer cells by assessment of apoptosis-related genes," Evidence-Based Complementary and Alternative Medicine, vol. 2012, Article ID 103026, 8 pages, 2012.

[57] W. K. Ng, L. S. Yazan, and M. Ismail, "Thymoquinone from Nigella sativa was more potent than cisplatin in eliminating of SiHa cells via apoptosis with down-regulation of Bcl-2 protein," Toxicology in Vitro, vol. 25, no. 7, pp. 1392-1398, 2011.

[58] L. Ding, Y. Huang, Q. Du et al., "TGEV nucleocapsid protein induces cell cycle arrest and apoptosis through activation of p53 signaling," Biochemical and Biophysical Research Communications, vol. 445, no. 2, pp. 497-503, 2014.

[59] D. Y. Takeda and A. Dutta, "DNA replication and progression through S phase," Oncogene, vol. 24, no. 17, pp. 2827-2843, 2005. 

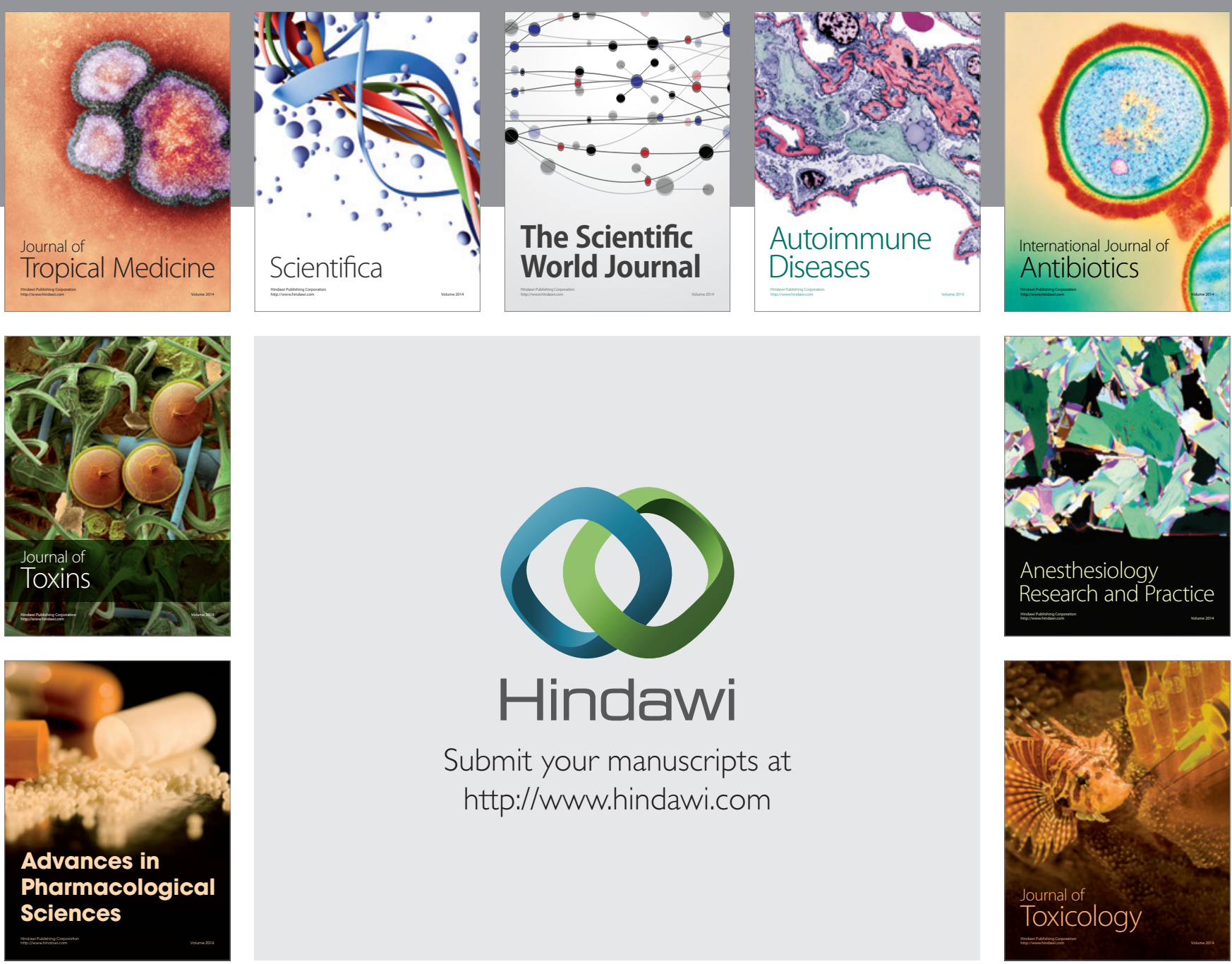

\section{Hindawi}

Submit your manuscripts at

http://www.hindawi.com
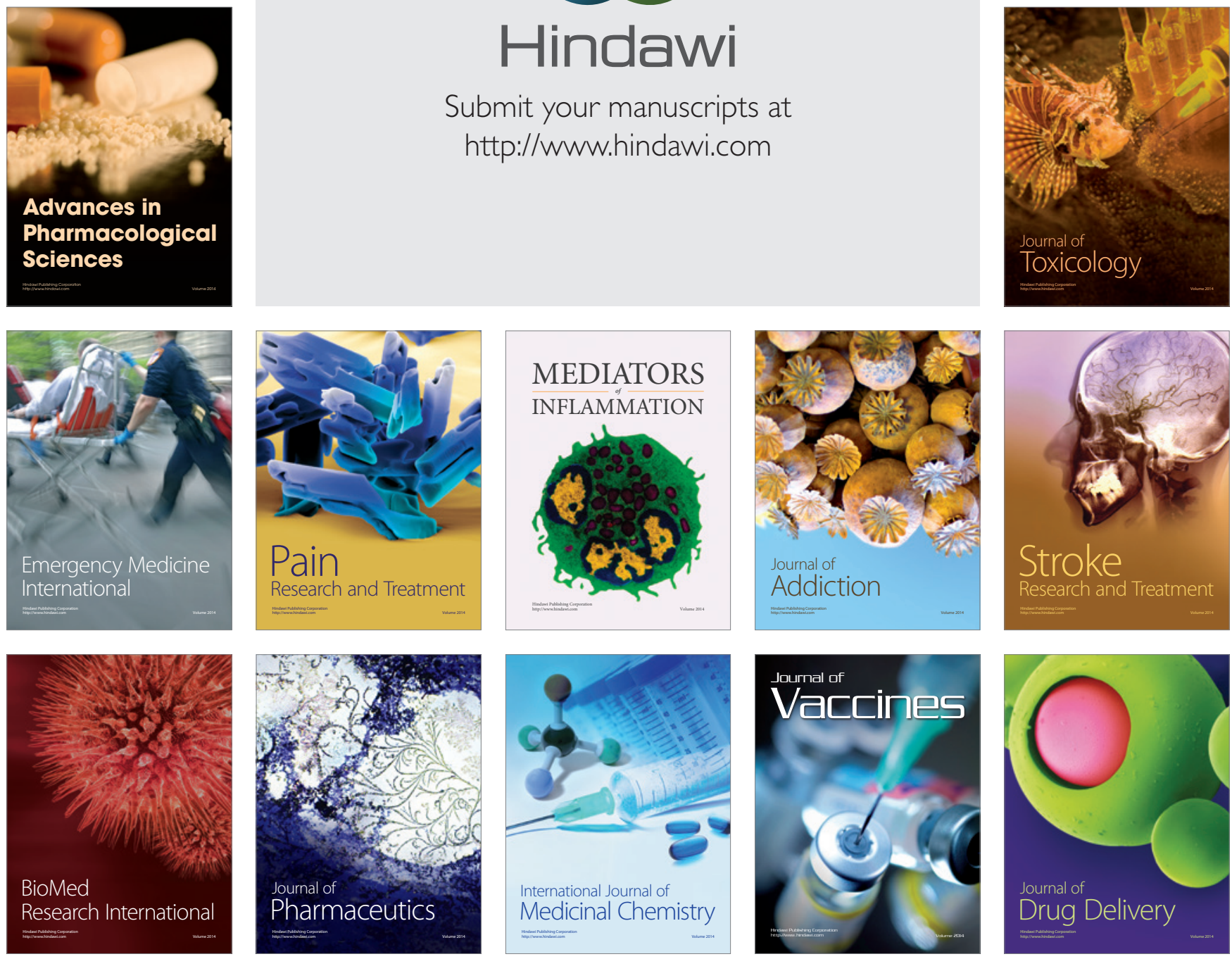